\title{
Effect of pH, Sucrose Concentrations and Medium States on in vitro Rooting of Pineapple (Ananas comosus (L) Merr) cv Queen
}

\author{
Abdelhamid M. Hamad \\ Horticulture Department, Faculty of Agriculture, Omar Al-Mukhtar University Al Bayda, Libya
}

Received: 21 February 2021/ Accepted: 15 June 2021

Doi: https://doi.org/10.54172/mjsc.v36i2.54

\begin{abstract}
The effect of medium states (liquid, semi solid, solid), $\mathrm{pH}$ (5.0, 5.5, 6.0, 6.5) and sucrose concentrations $(10,20,30,40 \mathrm{~g} / \mathrm{l})$ on in vitro rooting of pineapple cultured in full strength MS enriched with IBA at $0.5 \mathrm{mg} / \mathrm{l}$ were investigated. According to average overall sucrose concentrations, overall $\mathrm{pH}$ adjustments, and at each combination of equal sucrose and $\mathrm{pH}$, liquid medium was always super than solid and semisolid. The tallest plantlets (66 to $71 \mathrm{~mm}$ ) obtained in liquid medium enriched with sucrose at 10 and $20 \mathrm{~g} / \mathrm{l}$ both adjusted to $\mathrm{pH}$ 6.0; sucrose at $20 \mathrm{~g} / \mathrm{l}$ and adjusted to $\mathrm{pH}$ 6.5 and sucrose at $30 \mathrm{~g} / \mathrm{l}$ and adjusted to $\mathrm{pH}$ 5.0. All of the above combinations except sucrose at 20 and pH 6.0 resulted in 100\% rooting. Sucrose at $30 \mathrm{~g} / \mathrm{l}$ and $\mathrm{pH} 5.0$ resulted in two times more (11 roots per shoot) and three times longer roots $(39 \mathrm{~mm})$ than the other treatments (5 roots each about $14 \mathrm{~mm}$ long). Each rooting parameter had different optimum combinations of medium state, sucrose and $\mathrm{pH}$ adjustment. For any parameter, proper $\mathrm{pH}$ adjustment could reduce the optimal sucrose enrichment from 30 to 20 and even to $10 \mathrm{~g} / \mathrm{l}$. Hence, $\mathrm{pH}$ adjustment is suggested as an important approach for reduction of in vitro rooting medium cost.
\end{abstract}

Keywords: Medium state; $\mathrm{pH}$; Sucrose; In vitro rooting; Tissue culture; Ananas comosus

\section{INTRODUCTION}

In vitro rooting of pineapple were reported in medium solidified with phytagel at $2.5 \mathrm{~g} / \mathrm{l}$ (Ko et al., 2006), agar at 6 (Rahman et al., 2001), agar at 7 (De Almeida et al., 1997) and $8 \mathrm{~g} / \mathrm{l}$ (Akbar et al., 2003), in liquid medium using filter paper bridged (Soneji et al., 2002), sponge matrix (Gangopadhyay et al., 2005), Luffa matrix (Dutta et al., 2013), in static liquid medium; (Be \& Debergh, 2006; Hamad et al., 2013 ; Hamad, 2019) and ex vitro in potting mix (Escalona et al., 1999; Liu et al., 1989). The effect of both of liquid and solid medium at full and half strength enriched with different auxin types and concentrations on the in vitro rooting of pineapple were compared (Hamad et al., 2013). Several other factors such as different combination of hormone types, concen-trations and medium strength (Bhatia \& Ashwath, 2000; Firoozabady \& Gutterson, 2003), shoot ages and cultivars (Hamad et al., 2013) , mix of commercial sugar with sucrose (Dutta et al., 2013) were found to induce significant effect on the in vitro rooting responses of pineapple. Medium $\mathrm{pH}$ adjustment in all of these cases was kept fixed at $\mathrm{pH}$ 5.7, and sucrose enrichments, on the other hand, most of the cases kept fixed at $30 \mathrm{~g} / \mathrm{l}$. In some cases, sucrose at 20 (Ko et al., 2006; Sunitibala Devi et al., 1997) and $40 \mathrm{~g} / \mathrm{l}$ (De Almeida et al., 1997) in solid medium and at 20 (Soneji et al., 2002) and $35 \mathrm{~g} / \mathrm{l} \backslash$ (Kofi \& Adachi, 1993) in liquid medium was used for rooting.

In few cases the sucrose effect on rooting was compared at $2 \backslash$ (Mengesha et al., 2021), 3 (Zaied, 2007) and 4 (Almobasher, 2016; Hassan et al., 2018) different concentrations in solid medium and at 2 (Be \& Debergh, 2006) and 6 (Hamad, 2019) different concentrations in liquid medium. (Hassan et al., 2018; Zaied, 2007) reported that rooting occurred in solid MS medium with no sucrose

*Corresponding Author: Abdelhamid M Hamad abdelhamidhamad@gmail.com , Horticulture Department, Faculty of Agriculture, Omar AlMukhtar University Albayda, Libya 
enrichment but the best rooting was in medium enriched with sucrose at $20 \mathrm{~g} / \mathrm{l}$. On the contrary, (Mengesha et al., 2021) reported that no rooting could be obtained and shoots died in solid MS devoid of sucrose and (Almobasher, 2016) not only reported no rooting in solid MS medium devoid of sucrose but also in medium enriched with sucrose at $10 \mathrm{~g} / \mathrm{l}$ and both found best root formation and length in medium enriched with sucrose at $20 \mathrm{~g} / \mathrm{l}$. (Dutta et al., 2013) recommended mix of commercial sugar at $2 \%$ with sucrose at $1 \%$ in liquid with luffa support and Be and (Be \& Debergh, 2006) recommended sucrose enrichment of $30 \mathrm{~g} / \mathrm{l}$ for liquid MS medium. Hamad (2019) found that no rooting could be obtained in liquid MS medium enriched with sucrose at $5 \mathrm{~g} / \mathrm{l}$ and the optimum concentration ranged from 10 to 30 $\mathrm{g} / \mathrm{l}$ depending on the rooting parameters used for evaluation and varied according to the length of incubation period. In all of these studies of pineapple in vitro rooting, the medium $\mathrm{pH}$ was fixed at 5.7. The effect of different combinations of sucrose, medium states and $\mathrm{pH}$ adjustments still yet to be tested.

Cost of rooting stage (Hamad, 2019) was expected to be three times cost of multiplication stage (Hamad, 2017a and b). In large scale production, the cost of medium during rooting could be decisive factor for feasibility of micropropagation. Sucrose and agar made the largest portion of the medium components and are very important items of the medium cost. Rooting could occur in solid and liquid medium. That is complete elimination of agar cost is possible. On contrary, sucrose is an obligatory requirement for in vitro rooting and indispensable component of the medium (Almobasher, 2016; Mengesha et al., 2021 ; Hamad, 2019). Reduction of sucrose cost could be done either by using of cheap sucrose alternatives (Dutta et al., 2013; Mengesha et al., 2021; Nelson et al., 2015) or by using the most possible minimum concentration. In fact, (Dutta et al., 2013) reported that compared to solid media enriched with sucrose at $30 \mathrm{~g} / \mathrm{l}$ using of mix of commercial sugar with sucrose in liquid media with luffa matrix reduced the chemical cost of multiplication by $15 \%$ and rooting cost by $62 \%$. Sucrose is just a one of several factors that could have independent and interaction effect on rooting (Hamad, et al 2013; Hamad, 2019). Minimum sucrose concentration that would maintain highest response for each rooting parameter is expected to be different at different combinations of other root effecting factors such as medium state and $\mathrm{pH}$ adjustments. The objective of this study is to compare the effect of different $\mathrm{pH}$ adjustments (5.0, 5.5, 6.0 and 6.5) and agar concentrations $(0.0,3.5,7.0 \mathrm{~g} / \mathrm{l})$ on the rooting responses of Queen pineapple to different concentrations of sucrose $(10,20,30,40 \mathrm{~g} / \mathrm{l})$. The goal is to determine the $\mathrm{pH}$ of liquid medium that maintained the highest rooting responses at lowest sucrose concentration.

\section{MATERIALS AND METHODS}

One and half liter of MS medium (Murashige \& Skoog, 1962) was enriched with IBA at 0.5 $\mathrm{mg} / \mathrm{l}$ and divided into 4 beakers each received $312 \mathrm{ml}$ and marked A, B, C, and D. Sucrose at $10,20,30$ and $40 \mathrm{~g} / \mathrm{l}$ were added to beakers $\mathrm{A}, \mathrm{B}, \mathrm{C}$ and $\mathrm{D}$ respectively. The content of each beakers divided equally $(78 \mathrm{ml})$ into 4 glass jars marked with the same beaker symbol plus 1, 2, 3 and 4 . The content of jars numbered 1, 2, 3 and 4 adjusted to $\mathrm{pH}$ 5.0, $5.5,6.0$ and 6.5 respectively. Then the content of each jar divided equally $(26 \mathrm{ml})$ into another 3 glass jars marked with same symbol plus H, S and L. Agar at 3.5 and $7 \mathrm{~g} / \mathrm{l}$ added to glasses marked with $\mathrm{H}$ and $\mathrm{S}$ respectively, and the glass marked $\mathrm{L}$ without agar. The glasses covered with autoclavable plastic lid and the medium was then sterilized at $121^{\mathrm{O}} \mathrm{C}$ and $1.5 \mathrm{~kg} / \mathrm{cm}^{2}$ for 25 minutes. The content of each glass dispensed under laminar into 3 culture tubes marked as glass. Three shoots from stock cultures were cultured per each culture tube. The cultures incubated un- 
der photo-period of 16 hours of light and constant temperature of $25^{\circ} \mathrm{C}$. After 60 days of incubation, the cultures removed from the incubation room, the shoots picked out of the cultures and placed over squared paper, for counting of the roots and measuring the root and shoot length. Each tube was considered as one replicate and the data except shoot length (plantlet height) were transformed to square roots $(\mathrm{x}+1)$ before analysis of variance. Analysis of variance and Duncan Multiple Range Test for significant of treatments at $\mathrm{p} \leq 0.05$ were computed using SPSS statistical package No. 11.

\section{RESULTS}

Analysis of variance (Table 1) showed that sucrose had significant independent (direct) and dependent (indirect) effect via interaction with $\mathrm{pH}$ in all rooting parameters, and dependent (indirect) effect via interaction with agar (medium state) in two of the rooting parameters (root number and plantlet height). But the interaction in case of the other two parameters (rooting percentage and root length) was not significant. Medium state (agar) had significant independent effect (direct) in all rooting parameters except rooting percentage and dependent (indirect) effect via interaction with sucrose in two of rooting parameters (root number and plantlet height). Medium pH, on the other hand, did not have significant independent (direct) effect on any of the rooting parameters and did not interact significantly with agar concentrations (medium state). However, medium $\mathrm{pH}$ did have dependent (indirect) significant effect via interaction with sucrose in all rooting parameters, and via collective interaction with both of sucrose and agar (medium states) on all rooting aspects except the plantlets height. Overall sucrose concent-rations and $\mathrm{pH}$ adjustments (Table 2), liquid medium resulted in taller plantlets $(51.06 \mathrm{~mm})$, more $(5.38$ roots) and longer roots $(18.25 \mathrm{~mm})$ than solid medium (39 mm tall plantlets, 3.13 roots per shoots, $10.96 \mathrm{~mm}$ long each) but the rooting percentage of liquid (69.4\%) and solid (59 $\%)$ medium were not significantly different (Table 2). Similar, overall medium states and $\mathrm{pH}$ adjustments, the largest number (5.4 roots), longer roots $(16.25 \mathrm{~mm})$ and highest rooting percentage $(76.3 \%)$ obtained in medium enriched with sucrose at 20 and $30 \mathrm{~g} / \mathrm{l}$. However, sucrose at $20 \mathrm{~g} / \mathrm{l}$ resulted in tallest plantlets $(52.8 \mathrm{~mm})$ and sucrose at $30 \mathrm{~g} / \mathrm{l}$ resulted in an intermediate plantlet height $(48.08 \mathrm{~mm})$. Sucrose at 10 and $40 \mathrm{~g} / \mathrm{l}$ resulted in the lowest rooting percentage (47.0\%), fewest (2.1 roots) and shortest (6.7 mm long) roots, but the plantlets on medium enriched with sucrose at $10 \mathrm{~g} / \mathrm{l}$ was taller $(42.33 \mathrm{~mm})$ than that in medium with $40 \mathrm{~g} / \mathrm{l}(31.9 \mathrm{~mm})$. Overall medium states and sucrose, the $\mathrm{pH}$ adjustments of medium had no significant effect on any of the rooting parameters. On the other hand, overall $\mathrm{pH}$ adjustments, liquid medium enriched with sucrose at $30 \mathrm{~g} / \mathrm{l}$ resulted in highest rooting percentage (88\%) and more (8.8 roots) and longest roots (29 $\mathrm{mm}$ ) while semi solid enriched with sucrose at $10 \mathrm{~g} / \mathrm{l}$ resulted in lowest rooting percentage (31.3\%), and fewest (1 root per shoot) and shortest roots $(5.3 \mathrm{~mm})$. However, the tallest plantlets $(63 \mathrm{~mm})$, on the other hand, obtained in liquid medium enriched with sucrose at $20 \mathrm{~g} / \mathrm{l}$ while the shortest plantlets (28 and $30 \mathrm{~mm}$ ) obtained in semi solid and liquid medium enriched with sucrose at $40 \mathrm{~g} / \mathrm{l}$. No significant different on plantlet height on solid medium enriched with sucrose at 10 and $40 \mathrm{~g} / \mathrm{l}$ and semi solid enriched with sucrose at $10 \mathrm{~g} / \mathrm{l}$

Comparing of all combinations of sucrose, $\mathrm{pH}$ and medium states (Table 2) showed that the tallest plantlet (70 and $71 \mathrm{~mm}$ ) was obtained in liquid medium enriched with sucrose at 10 and $20 \mathrm{~g} / \mathrm{l}$ and adjusted to $\mathrm{pH} 6.0$ and the most stunted plantlets $(15.0 \mathrm{~mm})$ obtained on semi solid enriched with sucrose at $40 \mathrm{~g} / \mathrm{l}$ and adjusted to $\mathrm{pH} 5.0$ and $\mathrm{pH}$ 6.0. On the other hand, all shoots (100\%) could be rooted in liquid media enriched with sucrose at $10 \mathrm{~g} / \mathrm{l}$ and adjusted to $\mathrm{pH} 6.0$; sucrose at 20 
$\mathrm{g} / \mathrm{l}$ and $\mathrm{pH} 5.0$ and $\mathrm{pH}$ 6.5; sucrose at $30 \mathrm{~g} / \mathrm{l}$ and $\mathrm{pH} 5.0$ and on semi solid media enriched with sucrose at $20 \mathrm{~g} / \mathrm{l}$ and adjusted to $\mathrm{pH}$ 6.5; sucrose at $30 \mathrm{~g} / \mathrm{l}$ and $\mathrm{pH} 5.0$ and sucrose at 40 $\mathrm{g} / \mathrm{l}$ and $\mathrm{pH}$ 6.5. However, $100 \%$ rooting obtained in liquid medium could be reversed to $22 \%$ if enriched with sucrose at $10 \mathrm{~g} / \mathrm{l}$ and adjusted to $\mathrm{pH} 5.5$ and that of semi solid reversed to $11 \%$ if enriched with sucrose at 40 $\mathrm{g} / \mathrm{l}$ and adjusted to $\mathrm{pH} 5.0$ and 6.0. Contrary, none of the combinations in which solid medium was used irrespective of sucrose and $\mathrm{pH}$ and none of the combination in which the media adjusted to $\mathrm{pH} 5.5$ irrespective of sucrose and medium states resulted in $100 \%$ rooting. The highest rooting percentage in solid media was $89 \%$, obtained in medium enriched with sucrose at $20 \mathrm{~g} / \mathrm{l}$ and adjusted to $\mathrm{pH} 5.0$ and sucrose at $30 \mathrm{~g} / \mathrm{l}$ and $\mathrm{pH} 5.0$ and $\mathrm{pH}$ 5.5. Highest root formation (10-11 roots) obtained in liquid medium enriched with sucrose at 20 and $30 \mathrm{~g} / \mathrm{l}$ and adjusted to pH 5.0 and pH 5.5 and in solid medium enriched with sucrose at $30 \mathrm{~g} / \mathrm{l}$ and adjusted to
$\mathrm{pH}$ 5.0. The lowest root formation (1 root) obtained in almost all (75 \%) of the combinations in which the sucrose enrichment was 10 $\mathrm{g} / \mathrm{l}$ and in $50 \%$ of the combinations in which sucrose enrichment was $40 \mathrm{~g} / \mathrm{l}$. The longest root $(39 \mathrm{~mm})$ obtained on liquid medium enriched with sucrose at $30 \mathrm{~g} / \mathrm{l}$ and adjusted to $\mathrm{pH} 5.0$ and the shortest $(3.0 \mathrm{~mm})$ on semi solid medium enriched with sucrose at $10 \mathrm{~g} / \mathrm{l}$ and adjusted to $\mathrm{pH}$ 6.5; sucrose at $40 \mathrm{~g} / \mathrm{l}$ and adjusted to $\mathrm{pH} 5.0$ and $\mathrm{pH} 6.0$ and on solid medium enriched with sucrose at $10 \mathrm{~g} / \mathrm{l}$ and adjusted to $\mathrm{pH}$ 5.5.

Table. (1). Significant of main and interaction effect of medium states, sucrose concentrations and $\mathrm{pH}$ of full strength MS medium on the in vitro rooting of Queen pineapple.

\begin{tabular}{llllll}
\hline \hline \multirow{2}{*}{ Factors } & \multirow{2}{*}{$\mathrm{df}$} & \multicolumn{3}{c}{ Rooting parameters (p values) } \\
\cline { 3 - 5 } & & Plantlet height & Rooting \% & Root No. & Root length \\
\hline Medium states & 2 & $0.0001^{* *}$ & 0.1310 & $9.09 \mathrm{E}-07^{* *}$ & $5.14 \mathrm{E}-05^{* *}$ \\
Sucrose conc. & 3 & $5.19 \mathrm{E}-08^{* *}$ & $0.0001^{* *}$ & $1.53 \mathrm{E}-12^{* *}$ & $7.59 \mathrm{E}-09^{* *}$ \\
$\mathrm{pH}$ & 3 & 0.8404 & 0.5973 & 0.4395 & 0.1909 \\
State*Sucrose & 6 & $0.0103^{*}$ & 0.4861 & $0.0055^{* *}$ & 0.1382 \\
State*pH & 6 & 0.5682 & 0.2698 & 0.2666 & 0.4854 \\
Sucrose*pH & 9 & $1.07 \mathrm{E}-05^{* *}$ & $0.0238 * *$ & $1.23 \mathrm{E}-06^{* *}$ & $0.0004^{* *}$ \\
State*Sucrose*pH & 18 & 0.2315 & $0.0085^{* *}$ & $2.39 \mathrm{E}-05^{* *}$ & $0.0038^{* *}$ \\
Error & 96 & & & & \\
Total & 144 & & & & \\
\hline \hline
\end{tabular}


Table (2). Effect of medium states, sucrose concentrations and $\mathrm{pH}$ of full strength MS medium on the in vitro rooting of Queen pineapple

\begin{tabular}{|c|c|c|c|c|c|c|}
\hline Medium states & $\mathrm{pH}$ & Sucrose $(\mathrm{g} / \mathrm{l})$ & & & & \\
\hline$($ Agar/l) & & 10 & 20 & 30 & 40 & Average \\
\hline \multicolumn{7}{|c|}{ Plantlet height $(\mathrm{mm})$} \\
\hline Liquid & 5 & 55 bc & 56 bc & $66 \mathrm{ab}$ & 22 ef & $49.75 \mathrm{AB}$ \\
\hline \multirow[t]{4}{*}{$(0.0 \mathrm{~g} / \mathrm{l})$} & 5.5 & $61 \mathrm{abc}$ & $57 \mathrm{bc}$ & $60 \mathrm{abc}$ & $22 \mathrm{ef}$ & $50 \mathrm{AB}$ \\
\hline & 6 & $70 \mathrm{a}$ & $71 \mathrm{a}$ & 56 bc & 31 cdef & $57 \mathrm{~A}$ \\
\hline & 6.5 & 38 cde & $68 \mathrm{ab}$ & 38 cde & $46 \mathrm{~cd}$ & $47.5 \mathrm{AB}$ \\
\hline & Average & $56 \mathrm{AB}$ & $63 \mathrm{~A}$ & $55 \mathrm{AB}$ & $30.25 \mathrm{D}$ & 51.06 \\
\hline Semi solid & 5 & 52 bcd & $53 \mathrm{bc}$ & $56 \mathrm{bc}$ & $16 \mathrm{f}$ & $44.25 \mathrm{AB}$ \\
\hline \multirow[t]{4}{*}{$(3.5 \mathrm{~g} / \mathrm{l})$} & 5.5 & 32 cdef & $42 \mathrm{~cd}$ & 55 bc & 24 ef & 38.25 B \\
\hline & 6 & 38 cde & $65 \mathrm{ab}$ & $48 \mathrm{bcd}$ & $15 \mathrm{f}$ & $41.5 \mathrm{AB}$ \\
\hline & 6.5 & 27 def & 52 bcd & 27 def & $58 \mathrm{abc}$ & $41 \mathrm{AB}$ \\
\hline & Average & $37.25 \mathrm{CD}$ & $53 \mathrm{AB}$ & $46.5 \mathrm{BC}$ & $28.25 \mathrm{D}$ & 41.25 \\
\hline Solid & 5 & 33 cdef & 36 cde & 51 bcd & 32 cdef & $40.5 \mathrm{AB}$ \\
\hline \multirow[t]{5}{*}{ (7 g/l) } & 5.5 & 28 def & $42 \mathrm{~cd}$ & 56 bc & 27 def & 38.25 B \\
\hline & 6 & 30 cdef & $43 \mathrm{~cd}$ & 27 ef & $42 \mathrm{~cd}$ & 35.5 B \\
\hline & 6.5 & $44 \mathrm{~cd}$ & 39 cde & 37 cde & $48 \mathrm{bcd}$ & $42 \mathrm{AB}$ \\
\hline & Average & $33.75 \mathrm{CD}$ & 42.5 BCD & $42.75 \mathrm{BCD}$ & $37.25 \mathrm{CD}$ & 39.06 \\
\hline & Grand aver & 42.3 & 52.8 & 48.08 & 31.91 & 43.7 \\
\hline \multicolumn{7}{|l|}{ Rooting \% } \\
\hline Liquid & 5 & 44.3 abcde & $100 \mathrm{a}$ & $100 \mathrm{a}$ & 33.3 abcde & $69.4 \mathrm{NS}$ \\
\hline \multirow{4}{*}{$(0.0 \mathrm{~g} / \mathrm{l})$} & 5.5 & $22.3 \mathrm{de}$ & $89 \mathrm{abc}$ & $96.3 \mathrm{ab}$ & 37 abcde & $61.2 \mathrm{NS}$ \\
\hline & 6 & $100 \mathrm{a}$ & 44.3 abcde & 77.7 abcd & 78 abcd & 75 NS \\
\hline & 6.5 & 33.3 abcde & $100 \mathrm{a}$ & 78 abcd & 78 abcd & 72.3 NS \\
\hline & Average & $49.98 \mathrm{BCD}$ & $83.08 \mathrm{AB}$ & $88.0 \mathrm{~A}$ & 56.58 ABCD & 69.41 \\
\hline Semi solid & 5 & 66.7 abcde & 77.7 abcd & 100 a & $11 \mathrm{e}$ & $63.8 \mathrm{NS}$ \\
\hline \multirow{4}{*}{$(3.5 \mathrm{~g} / \mathrm{l})$} & 5.5 & 22 bcde & 55.7 abcde & 55.7 abcde & 44.3 abcde & 44.4 NS \\
\hline & 6 & 22 bcde & 89 abc & 77.7 abcd & $11 \mathrm{e}$ & 49.9 NS \\
\hline & 6.5 & $14.7 \mathrm{de}$ & 100 a & 55.7 abcde & $100 \mathrm{a}$ & 67.6 NS \\
\hline & Average & $31.3 \mathrm{D}$ & $80.6 \mathrm{AB}$ & $72.3 \mathrm{ABC}$ & $41.6 \mathrm{CD}$ & 56.42 \\
\hline Solid & 5 & 33.3 abcde & 89 abc & 89 abc & 44.3 abcde & $63.9 \mathrm{NS}$ \\
\hline \multirow[t]{5}{*}{ (7.0 g/l) } & 5.5 & 22 bcde & 77.7 abcd & 89 abc & 55.3 abcde & $61 \mathrm{NS}$ \\
\hline & 6 & 44.3 abcde & 77.7 abcd & 44.3 abcde & 89 abc & 63.8 NS \\
\hline & 6.5 & 78 abcd & 33.3 cde & 33.3 cde & 44.3 abcde & $47.3 \mathrm{NS}$ \\
\hline & Average & $44.4 \mathrm{CD}$ & $69.4 \mathrm{ABC}$ & 63.9 ABCD & $58.3 \mathrm{ABCD}$ & 59 \\
\hline & Grand Aver & 41.89 & 77.69 & 74.78 & 52.16 & 61.63 \\
\hline \multicolumn{7}{|l|}{ Root number } \\
\hline Liquid & 5 & $1 \mathrm{hi}$ & $10 \mathrm{ab}$ & $11 \mathrm{a}$ & $1 \mathrm{hi}$ & $5.75 \mathrm{AB}$ \\
\hline \multirow[t]{4}{*}{$(0.0 \mathrm{~g} / \mathrm{l})$} & 5.5 & $1 \mathrm{hi}$ & $10 a b$ & $11 \mathrm{a}$ & 3 defgh & $6.25 \mathrm{~A}$ \\
\hline & 6 & 5 abcdef & 3 defgh & 7 abcd & 4 cdefg & $4.75 \mathrm{~B}$ \\
\hline & 6.5 & $1 \mathrm{hi}$ & 6 abcde & 6 abcde & 6 abcde & $4.75 \mathrm{~B}$ \\
\hline & Average & $2 \mathrm{CDE}$ & $7.3 \mathrm{AB}$ & $8.8 \mathrm{~A}$ & $3.5 \mathrm{CD}$ & 5.38 \\
\hline \multirow{5}{*}{$\begin{array}{l}\text { Semi solid } \\
(3.5 \mathrm{~g} / \mathrm{l})\end{array}$} & 5 & $1 \mathrm{hi}$ & 3 defgh & 8 abc & $0 \mathrm{i}$ & $3 \mathrm{CD}$ \\
\hline & 5.5 & $1 \mathrm{hi}$ & 2 efghi & 3 defgh & 2 efgh & $2 \mathrm{D}$ \\
\hline & 6 & $0 \mathrm{i}$ & 7 abcd & 6 abcde & $1 \mathrm{hi}$ & $3.5 \mathrm{BC}$ \\
\hline & 6.5 & $0 \mathrm{i}$ & 5 abcdef & 2 efgh & 4 cdefg & 2.75 CD \\
\hline & Average & $0.5 \mathrm{E}$ & $4.25 \mathrm{CD}$ & $4.75 \mathrm{BC}$ & $1.75 \mathrm{DE}$ & 2.81 \\
\hline Solid & 5 & $1 \mathrm{hi}$ & 5 bcdef & $11 \mathrm{a}$ & $1 \mathrm{hi}$ & $4.5 \mathrm{~B}$ \\
\hline \multirow[t]{5}{*}{$(7 \mathrm{~g} / \mathrm{l})$} & 5.5 & $1 \mathrm{hi}$ & 2 efgh & 7 abcd & 4 cdefg & $3.5 \mathrm{BC}$ \\
\hline & 6 & 2 efgh & 2 efgh & $1 \mathrm{hi}$ & 6 abcde & 2.75 CD \\
\hline & 6.5 & 4 cdefg & $1 \mathrm{hi}$ & $1 \mathrm{hi}$ & $1 \mathrm{hi}$ & $1.75 \mathrm{D}$ \\
\hline & Average & $2 \mathrm{CDE}$ & $2.5 \mathrm{CDE}$ & $5 \mathrm{BC}$ & $3 \mathrm{CD}$ & 3.12 \\
\hline & Grand aver & 1.5 & 4.68 & 6.18 & 2.75 & 3.77 \\
\hline
\end{tabular}

(C) 2021 The Author(s). This open access article is distributed under a CC BY-NC 4.0 license.

ISSN: online 2617-2186 print 2617-2178 


\begin{tabular}{|c|c|c|c|c|c|c|}
\hline \multirow{2}{*}{$\begin{array}{l}\text { Medium states } \\
\text { (Agar/l) }\end{array}$} & \multirow[t]{2}{*}{$\mathrm{pH}$} & \multicolumn{5}{|c|}{ Sucrose (g/l) } \\
\hline & & 10 & 20 & 30 & 40 & Average \\
\hline \multicolumn{7}{|c|}{ Root length (mm) } \\
\hline Liquid & 5 & 14 bcd & $24 \mathrm{abc}$ & $39 \mathrm{a}$ & 8 cde & $21.3 \mathrm{~A}$ \\
\hline \multirow[t]{4}{*}{$(0.0 \mathrm{~g} / \mathrm{l})$} & 5.5 & 9 cde & 27 abc & 28 abc & 6 cde & $17.5 \mathrm{AB}$ \\
\hline & 6 & 16 abcd & 12 bcd & $37 \mathrm{ab}$ & 12 bcd & $19.3 \mathrm{~A}$ \\
\hline & 6.5 & 4 de & 20 abcd & 12 bcd & 25 abc & $15.3 \mathrm{AB}$ \\
\hline & Average & $10.8 \mathrm{CD}$ & $20.5 \mathrm{AB}$ & $29 \mathrm{~A}$ & $12.8 \mathrm{BCD}$ & 18.25 \\
\hline Semi solid & 5 & 9 cde & 14 bcd & $24 \mathrm{abc}$ & $3 \mathrm{e}$ & $12.5 \mathrm{AB}$ \\
\hline \multirow[t]{4}{*}{$(3.5 \mathrm{~g} / \mathrm{l})$} & 5.5 & 4 de & $11 \mathrm{bcd}$ & 8 cde & 7 cde & $7.5 \mathrm{~B}$ \\
\hline & 6 & 5 de & 25 abc & $14 \mathrm{bcd}$ & 3 e & $11.8 \mathrm{AB}$ \\
\hline & 6.5 & 3 e & 25 abc & 8 cde & 15 bcd & $12.8 \mathrm{AB}$ \\
\hline & Average & $5.3 \mathrm{D}$ & $18.75 \mathrm{AB}$ & $13.5 \mathrm{BC}$ & $7 \mathrm{CD}$ & 11.15 \\
\hline Solid & 5 & 10 bcd & 15 bcd & 26 abc & 6 cde & $14.3 \mathrm{AB}$ \\
\hline \multirow[t]{5}{*}{$(7.0 \mathrm{~g} / \mathrm{l})$} & 5.5 & 3 e & $14 \mathrm{bcd}$ & 24 abc & 7 cde & $12 \mathrm{AB}$ \\
\hline & 6 & 7 cde & $11 \mathrm{bcd}$ & 6 cde & $14 \mathrm{bcd}$ & $9.5 \mathrm{AB}$ \\
\hline & 6.5 & 12 bcd & 7 cde & 7 cde & 6 cde & $8 \mathrm{~B}$ \\
\hline & Average & $8 \mathrm{CD}$ & 11.8 BCD & $15.75 \mathrm{BC}$ & 8.3 CD & 10.96 \\
\hline & Grand aver & 8.03 & 17.01 & 19.41 & 9.36 & 13.45 \\
\hline
\end{tabular}

Means of each rooting parameter followed by small letters and overall average followed by capital letters were not significantly different at $\mathrm{p}$ $\leq 0.05$ according to Duncan Multiple Range Test.

NS. (Not significant).

\section{DISCUSSION}

Previous reported studies of in vitro rooting assessed the rooting treatment based on one parameter, rooting percentage (Bhatia \& Ashwath, 2000), root number (Danso et al., 2008). In some cases two parameters, root number and length (Almobasher, 2016; Aydieh et al., 2000; Khatun et al., 1997) and in few cases three parameters: rooting percentage, root number and length (Amin et al., 2005; Soneji et al., 2002) were used for assessment of rooting treatments. Results (Table, 2) showed that assessment of rooting treatment based on one or two parameters could not be claimed as best rooting treatment. Different combinations of sucrose, $\mathrm{pH}$ and medium state could be recommended based in which parameter was used for assessment of treatments. Out of 48 combinations, seven resulted in $100 \%$ rooting, five in tallest plantlets (65 to $71 \mathrm{~mm}$ ), five in highest root number (10 - 11 roots) and two in longest roots $(37,39 \mathrm{~mm})$. Not only at any fixed $\mathrm{pH}$ and medium state, different rooting parameters have different optimal sucrose enrichment and each single rooting parameter could have several optimum combinations of $\mathrm{pH}$, medium state and sucrose enrichment but (C) 2021 The Author(s). This open access article is distributed under a CC BY-NC 4.0 license. ISSN: online 2617-2186 print 2617-2178 also combination which optimum for one parameter could suppress or promote another one, two or three rooting parameter. Two combinations (liquid enriched with sucrose at $10 \mathrm{~g} / \mathrm{l}, \mathrm{pH}$ 6.0; sucrose at $20 \mathrm{~g} / \mathrm{l}, \mathrm{pH}$ 6.5) was optimal for rooting percentage $(100 \%)$ and plantlet height (68 and $70 \mathrm{~mm}$ ) but suppressed root number from 11 to 5 and 6 roots and root length from 39 to 16 and $20 \mathrm{~mm}$ respectively. Other two combinations (liquid enriched with sucrose at $20 \mathrm{~g} / \mathrm{l} \mathrm{pH} 5.0$ and sucrose at $30 \mathrm{~g} / \mathrm{l}, \mathrm{pH}$ 5.5) was optimum for rooting percentage (100 and $96 \%$ ) and root number (10 and 11 roots) but suppressed the plantlet height from 70 to 56 and $60 \mathrm{~mm}$ and root length from 39 to 24 and $28 \mathrm{~mm}$ respectively. Semi sold medium enriched with sucrose at $20 \mathrm{~g} / \mathrm{l}$ and adjusted to $\mathrm{pH}$ 6.5, sucrose at $30 \mathrm{~g} / \mathrm{l}$ and $\mathrm{pH} 5.0$ and sucrose at 40 $\mathrm{g} / \mathrm{l}$ and $\mathrm{pH} 6.5$ was optimum only for rooting percentage (100\%). Liquid medium enriched with sucrose at $20 \mathrm{~g} / \mathrm{l}$ and adjusted to $\mathrm{pH} 6.0$ was optimum only for plantlet height (71 $\mathrm{mm})$. Liquid medium enriched with sucrose at 20 and $30 \mathrm{~g} / \mathrm{l}$ and adjusted to $\mathrm{pH} 5.5$ and solid medium enriched with sucrose at $30 \mathrm{~g} / \mathrm{l}$ and adjusted to pH 5.0 was optimum only for root number (10 to11 roots). Liquid medium 
enriched with sucrose at $30 \mathrm{~g} / \mathrm{l}$ and adjusted to $\mathrm{pH} 6.0$ was optimum only for root length (37 mm).

Generally, in vitro rooting is done for propagation purposes or physiological studies and best treatment should be judged based on parameters that serve the goals of propa-gators and physiologist. For propagation purposes selection of rooting treatment will be in favor of low cost and particular parameter quality which is very essential for higher survival of acclimatization. Assess-ment based on one parameter will be in favor of liquid over solid medium; lower over higher sucrose; shorter and fewer over longer and more roots for easy handling of acclimatization stage. If assessment based on rooting percentage (100 $\%)$ the cheapest combination was sucrose at $10 \mathrm{~g} / \mathrm{l}$ and $\mathrm{pH} 6.0$ and if for tallest plantlets (70 mm) the cheapest was also liquid medium enriched with sucrose at 10 and $\mathrm{pH}$ 6.0. For highest roots number (10 roots), the cheapest one was liquid medium enriched with $20 \mathrm{~g} / \mathrm{l}$ and adjusted to $\mathrm{pH} 5.0$ and 5.5. Two treatments resulted in longest roots, 39 and 37 $\mathrm{mm}$. (liquid enriched with sucrose at $30 \mathrm{~g} / \mathrm{l}$ adjusted to $\mathrm{pH} 5.0$ and $\mathrm{pH} 6.0$ ) and both were of equal cost (equal sucrose enrichment). If, more than one parameters included for assessment of rooting treatments, the choice will be compromise between possible best response of both parameters and low cost of the treatment. For both of rooting percentage (100\%) and plantlet height (70 mm), the best conciliation for both parameters, and low cost would be liquid medium enriched with sucrose at $10 \mathrm{~g} / \mathrm{l}$ and adjusted to $\mathrm{pH}$ 6.0. For rooting percentage $(100 \%)$ and root number (10 roots), the best compromise between best results and low cost would be liquid medium enriched with sucrose at $20 \mathrm{~g} / \mathrm{l}$ and adjusted to $\mathrm{pH}$ 5.0. None of the combinations was best for three and only one combination (liquid medium enriched with sucrose at $30 \mathrm{~g} / \mathrm{l}$ and adjusted to $\mathrm{pH}$ 5.0) was the best compromise for all of four rooting parameters (100 \% rooting, $66 \mathrm{~mm}$ tall plantlets, 11 roots, $39 \mathrm{~mm}$ long). It is clear that in liquid medium, simple manipulation of medium $\mathrm{pH}$ could reduce the optimum sucrose from 30 $\mathrm{g} / \mathrm{l}$ to $20 \mathrm{~g} / \mathrm{l}$ by adjusting the medium to $\mathrm{pH}$ 6.5 and even to $10 \mathrm{~g} / \mathrm{l}$ by adjusting to $\mathrm{pH}$ 6.0. Obtaining $100 \%$ of rooting and $70 \mathrm{~mm}$ tall plantlets with 5 roots each $16 \mathrm{~mm}$ long in liquid medium enriched with sucrose at $10 \mathrm{~g} / \mathrm{l}$ by adjusting the medium to $\mathrm{pH} 6.0$ is very important approach for reduction of in vitro rooting cost. It is simpler and easier approach than using of cheap sucrose alternative at fixed $\mathrm{pH}$ of 5.7 as mean of cost reduction in micropro-pagation of pineapple (Dutta et al., 2013; Mengesha et al., 2021; Nelson et al., 2015), banana (Kodym \& Zapata-Arias, 2001) and several plant species (Gangopadhyay et al., 2002).

Future investigation of combinations of low concentration range of 5 to $20 \mathrm{~g} / \mathrm{l}$ of cheap sucrose alternative and wider $\mathrm{pH}$ range of 3.5 to 8.0 may lead to optimum sucrose enrichment lower than $10 \mathrm{~g} / \mathrm{l}$, and substantial reduction in cost of rooting medium and worth being tested. Since cost of rooting (Hamad, 2019) is expected to be about three times cost of multiplication (Hamad, 2017a and b) any effort for minimizing the cost of rooting will be very important for reduction of total cost of micropropagation. In large scale production any small reduction of sucrose enrichment per liter of medium could be turning point for commercially feasible micropropagation system.

In most of in vitro rooting studies the relation between the rooting parameter and survival during acclimatization was not tested. A little attention was paid to determine which rooting parameter is more important than the others for survival, and what are the lower limit of the parameter required for survival. Nevertheless, (Escalona et al., 1999) reported that the survival percentage of ex vitro acclimatized rootless shoots increased from 20 to 100 $\%$ as the size of the shoots increased from 20 to $80 \mathrm{~mm}$ long (Be \& Debergh, 2006; Dal 
Vesco et al., 2001; DeWald et al., 1988; Ko et al., 2006; Soneji et al., 2002) respectively reported that over $90 \%$ of 35, 50, 60, 70 and $80 \mathrm{~mm}$ tall plantlets survived acclimatization stage. For pineapple, plantlet height is probably more crucial for acclimatization survival. However, the effect of different rooting treatment on the plantlet height was rarely reported (Hamad, 2019; Be \& Debergh, 2006; Hamad et al., 2013; Hassan et al., 2018), and was not tested as factor for survival of acclimatization stage. For better selection of treatments and proper micropropagation system, rooting and acclimatization treatments should be evaluated in connection with each other. After rooting stage the plantlets should be separated into groups according to root number, root length and plantlet height before being subject to acclimatization treatments. Assessment of rooting. Treatments should not only base on comparison of parameters, but in which rooting treatment and which rooting parameter resulted in highest acclimatization survival. Selection of best rooting treatment should be based on particular parameter with specific quality, which result in highest survival than the other parameters.

Medium pH adjustment determined the optimum sucrose enrichment for each rooting parameter on different medium states (Table, 2) and could switch the nature of sucrose and medium state interaction from enhancing to retarding rooting responses. In all medium states (liquid, semi solid and solid) in which the $\mathrm{pH}$ was adjusted to 5.0 and 5.5, the optimum sucrose for rooting \%, root number, root length and plantlet height was $30 \mathrm{~g} / \mathrm{l}$. However, if the medium $\mathrm{pH}$ was adjusted to 6.0 , the optimum sucrose for rooting responses in solid and semi solid was $20 \mathrm{~g} / \mathrm{l}$, while in liquid medium the optimum sucrose was 10 $\mathrm{g} / \mathrm{l}$. If the medium $\mathrm{pH}$ adjusted to 6.5, the optimum sucrose for rooting response in liquid and semi solid was $20 \mathrm{~g} / \mathrm{l}$, while in solid medium was $10 \mathrm{~g} / \mathrm{l}$. Adjustment of semi solid medium $\mathrm{pH}$ to (5.0 and 6.0) and enrichment with low (10 g/l) and high sucrose (40 g/l) promoted rooting percentage but retarded root number while in liquid medium improved both process of rooting \% and root number. Solid medium, on the contrary, suppressed root number if enriched with sucrose at 10 and $40 \mathrm{~g} / \mathrm{l}$ and suppressed rooting percentage but improved root number if enriched with sucrose at 20 and $30 \mathrm{~g} / \mathrm{l}$. Semi solid, on the other hand, improved both process of rooting percentage and root number. All shoots in liquid medium enriched with sucrose at $10 \mathrm{~g} / \mathrm{l}$ and adjusted to $\mathrm{pH} 6.0$ and sucrose at $30 \mathrm{~g} / \mathrm{l}$ and adjusted to $\mathrm{pH} 5.0$ rooted (100\%) and developed into 66 and $70 \mathrm{~mm}$ tall plantlets. However, the second treatment resulted in two times (11 roots) more and longer $(39 \mathrm{~mm})$ roots than the first treatment (5 roots, $16 \mathrm{~mm}$ ). Shoots cultured in liquid medium enriched with sucrose at $20 \mathrm{~g} / \mathrm{l}$ and adjusted to $\mathrm{pH} 6.0$, and in medium enriched with sucrose at $10 \mathrm{~g} / \mathrm{l}$ and adjusted to $\mathrm{pH} 5.5$ developed in taller plantlets (71 and $61 \mathrm{~mm}$ ) but these treatments failed to induce more than $45 \%$ rooting. Being seven combinations resulted in $100 \%$ rooting but in different number and length root, implied that root initials might have been formed in all of these combinations, but its growth arrested under some combinations of sucrose and $\mathrm{pH}$ and promoted under others. Low and high sucrose did not support root development. Histological study of apple in vitro rooting showed that initiation of root initials depended on IBA while development and growth of roots depended on sucrose enrichment (Harbage et al., 1993).

At fixed sucrose of 10, 20 and $30 \mathrm{~g} / \mathrm{l}$, increasing $\mathrm{pH}$ up to 6.5 decreased rooting percentage. while at fixed $\mathrm{pH}$ of 5.0, 5.5, 6.0 and 6.5 increasing sucrose enrichment up to $30 \mathrm{~g} / \mathrm{l}$ increased rooting percentage. However, on the contrary at fixed sucrose of $40 \mathrm{~g} / \mathrm{l}$ increasing medium $\mathrm{pH}$ up to 6.5 cause an increase of rooting percentage. This indicated that higher sucrose enrichment suppressed rooting and that suppression could be allevi- 
ated by increasing medium $\mathrm{pH}$. Increasing of rooting in medium enriched with sucrose at $40 \mathrm{~g} / \mathrm{l}$ by increasing the medium $\mathrm{pH}$ indicated that the $\mathrm{pH}$ interference kept sucrose accessibility and /or absorbed amount of sucrose below the limit that retard root initiation and development. Statistical analysis (Table 1) showed that sucrose had independent significant effect on rooting percentage and interacted significantly with $\mathrm{pH}$, while $\mathrm{pH}$ did not had significant independent effect on rooting percentage. Medium state, on other hand, neither had independent effect nor interacted with sucrose or with $\mathrm{pH}$. Root number and root length, on the other hand, was under independent effect of both sucrose and medium state and interaction of sucrose with $\mathrm{pH}$ and sucrose with medium state.

On the same time, all of the three parameters was not effected by $\mathrm{pH}$ and interaction of $\mathrm{pH}$ with medium state but all of the three rooting parameters (rooting \%, root number and root length) was under collective significant interaction of the three factors (sucrose medium state and $\mathrm{pH}$ ). This indicated that the collective interaction occurred in two steps: First, the sucrose interacted with $\mathrm{pH}$ to produce an intermediate product or condition that trigger initiation process of root premordia (significant effect in rooting percentage). Second, medium state interacted with the product or condition resulted from sucrose $\mathrm{pH}$ interaction and facilitate root growth and development. Neither the effect of medium state alone nor the interaction of medium state with sucrose or $\mathrm{pH}$ on the rooting percentage was significant (Table, 1) Medium states. did not effects the process of root premordia initiation, but facilitated root growth and penetration of internal tissues of the shoots. Once emerged, the root elongation in liquid was faster than in solid media. The importance of medium $\mathrm{pH}$ for in vitro rooting is not understood yet. The effect varied among different plants and media. Lowering of $\mathrm{pH}$ from 5.7 to 4.7 reduced the rooting percentage of Geraldton wax from 63 to $20 \%$ (Page \&
Visser, 1989), while lowering the $\mathrm{pH}$ from 5.7 to 4.0 increased the rooting percentage of Australian woody plants from 28 to $100 \%$ (Williams et al., 1985). In a solid WPM medium enriched with sucrose at $30 \mathrm{~g} / \mathrm{l}$, lowering the $\mathrm{pH}$ from 5.7 to 3.5 decreased the rooting of Choisya ternata by up to $60 \%$ and Delphinium by $15 \%$ (Leifert et al., 1992). At fixed concentration of sucrose (30 g/l), using of solid and liquid MS medium and adjusting the $\mathrm{pH}$ to range of 4.2 up to 6.2 did not affect the rooting percentage of Maranta leuconeura cv Kerchoviana (Bennett et al., 2003; Ebrahim \& Ibrahim, 2000) reported that the lower rooting percentage (62 \%) and few roots (4 roots) of Eucalyptus glabulus were mainly due to presence of NHNO. In medium devoid of NHNO, rooting increased to $94 \%$ and roots to 7 roots per shoot over $\mathrm{pH}$ range of 4.0 to 6.0. (Harbage et al., 1993) noticed that the optimal $\mathrm{pH}$ for root formation of $\mathrm{Ga}$ la apple varied at different concentration of IBA. Increasing the sucrose concentration shifted the in vitro rooting dose-response curve of Jork 9 apple to auxin to the right (Calamar \& De Klerk, 2002). Our results indicated that for in vitro rooting of pineapple, the rooting dose response curve to sucrose could be shifted by medium $\mathrm{pH}$ and the sucrose concentration could be minimized by adjusting the medium to proper $\mathrm{pH}$.

Most of the reported rooting studies used either solid or liquid medium at full or half strength at fixed sucrose of $30 \mathrm{~g} / \mathrm{l}$ and $\mathrm{pH} 5.7$ and recommended different concentration and combination of rooting hormones. For assessment of rooting treatments some used only one parameter and others used two or three rooting parameters and come up with different recommendations for in vitro rooting depending in which parameter was used for assessment and which factors was included in testing of rooting. In this study, liquid medium enriched with sucrose at $30 \mathrm{~g} / \mathrm{l}$ and adjusted to $\mathrm{pH} 5.0$ was optimum for all rooting parameters, (100\% rooting, $66 \mathrm{~mm}$ tall plantlet with11 roots per shoot each $39 \mathrm{~mm}$ long. 
However, none of the treatments recommended in previous studies or in this study could be adopted as a universal treatment for rooting unless the cost of rooting kept at its lowest. The crucial rooting parameter for survival of acclimatization identified, and the mode of the factor effect on each of the three physiological steps of rooting elucidated. Future studies of in vitro rooting should focus in determining the relation between rooting parameters and percentage of survival during acclimatization. The two stages should be studied in connection with each other. Determining of optimum combination for each single rooting parameter as done in this study will help in selection of the most proper treatment and best timing for histological, physiological and biochemical study of root formation steps.

\section{REFERENCES}

Akbar, M. A., Karmakar, B. K., \& Roy, S. K. (2003). Callus induction and highfrequency plant regeneration of Pineapple (Ananas comosus (L.) Merr.).

Almobasher, H. A. A. (2016). In vitro Rhizogenesis of Pineapple (Ananas comosus L.) 'Smooth Cayenne 'Cultivar.

Amin, M., Rahman, M., Rahman, K., Ahmed, R., Hossain, M., \& Ahmed, M. (2005). Large scale plant regeneration in vitro from leaf derived callus cultures of pineapple [Ananas comosus (L.) Merr. cv. Giant Kew]. International journal of botany.

Aydieh, A., Ibrahim, M., \& Ibrahim, A. (2000). In vitro propagation and fruiting of pineapple. Egyptian Journal of Horticulture, 27(3), 289-304.

Be, L., \& Debergh, P. (2006). Potential lowcost micropropagation of pineapple (Ananas comosus). South African Journal of Botany, 72(2), 191-194.
Bennett, I. J., McDavid, D., \& McComb, J. (2003). The influence of ammonium nitrate, $\mathrm{pH}$ and indole butyric acid on root induction and survival in soil of micropropagated Eucalyptus globulus. Biologia Plantarum, 47(3), 355-360.

Bhatia, P., \& Ashwath, N. (2000). Development of a rapid method for micropropagation of a new pineapple [Ananas comosus (l.) Murr.] clone,'Yeppoon gold'. International Symposium on Tropical and Subtropical Fruits 575,

Calamar, A., \& De Klerk, G.-J. (2002). Effect of sucrose on adventitious root regeneration in apple. Plant Cell, Tissue and Organ Culture, 70(2), 207-212.

Dal Vesco, L. L., de Almeida Pinto, A., Zaffari, G. R., Nodari, R. O., Dos Reis, M. S., \& Guerra, M. P. (2001). Improving pineapple micropropagation protocol through explant size and medium composition manipulation. Fruits, 56(3), 143-154.

Danso, K., Ayeh, K., Oduro, V., Amiteye, S., \& Amoatey, H. (2008). Effect of 6Benzylaminopurine and-Naphthalene Acetic Acid on In vitro Production of MD2 Pineapple Planting Materials. World Applied Sciences Journal, 3(4), 614-619.

De Almeida, W., De Matos, A., \& Souza, A. d. S. (1997). Effects of benzylaminopurine (BAP) on in vitro proliferation of pineapple (Ananas comosus (L.) Merr.). II International Pineapple Symposium 425,

DeWald, M., Moore, G., Sherman, W., \& Evans, M. (1988). Production of pineapple plants in vitro. Plant cell reports, $7(7)$, 535-537. 
Dutta, I., Bhadra, J., Ghosh, P., Saha, B., \& Datta, S. (2013). An Efficient and Cost Effective Protocol for In Vitro Propagation of Pineapple.

Ebrahim, M. K., \& Ibrahim, I. A. (2000). Influence of medium solidification and $\mathrm{pH}$ value on in vitro propagation of Maranta leuconeura cv. Kerchoviana. Scientia Horticulturae, 86(3), 211-221.

Escalona, M., Lorenzo, J., González, B., Daquinta, M., González, J., Desjardins, Y., \& Borroto, C. (1999). Pineapple (Ananas comosus L. Merr) micropropagation in temporary immersion systems. Plant cell reports, 18(9), 743-748.

Firoozabady, E., \& Gutterson, N. (2003). Costeffective in vitro propagation methods for pineapple. Plant cell reports, 21(9), 844-850.

Gangopadhyay, G., Bandyopadhyay, T., Poddar, R., Gangopadhyay, S. B., \& Mukherjee, K. K. (2005). Encapsulation of pineapple micro shoots in alginate beads for temporary storage. Current Science, 972-977.

Gangopadhyay, G., Das, S., Mitra, S., Poddar, R., Modak, B., \& Mukherjee, K. (2002). Enhanced rate of multiplication and rooting through the use of coir in aseptic liquid culture media. Plant Cell, Tissue and Organ Culture, 68(3), 301310.

Hamad, A. H. M., Taha, R. M., \& Mohajer, S. (2013). In vitro induction and proliferation of adventitious roots in pineapple (Ananas comosus L.) cultivars of smooth cayenne and morris. Australian Journal of Crop Science, 7(7), 1038-1045.
Hamad, A. M. (2017a). Effect of incubation periods, medium volumes and explants density on the in vitro shoot formation and growth and cost of multiplication of Moris pineapple. El Mukhtar J. of Sciences, 33 (1): 10 -16.

Hamad, A. M. (2017b). Effect of explants density, medium volumes and subcultures on the in vitro shoot formation and cost of multiplication of Moris pineapple (Ananas comosus L. Merr). Libyan J of Basic Sciences 7 (1): 78- 90 .

Hamad, A. H. (2019). Effect of sucrose concentrations and incubation periods on in vitro rooting of Moris pineapple (Ananas comosus). Al-Mukhtar J. of Sciences, 34 (4): 230 - 242.

Harbage, J. F., Stimart, D. P., \& Evert, R. F. (1993). Anatomy of adventitious root formation in microcuttings of Malus domestica Borkh.Gala'. Journal of the American Society for Horticultural Science, 118(5), 680-688.

Hassan, S., Waly, A., Bakry, A., \& ElKaramany, B. (2018). In vitro study on the effect of hydrogel on rooting and acclimatization of pine apple (Ananas comosus cV. Smooth cayenne). BIOSCIENCE RESEARCH, 15(3), 2358-2363.

Khatun, M., Khanam, D., Hoque, M., \& Quasem, A. (1997). Clonal propagation of pineapple through tissue culture. Plant Tissue Cult, 7(2), 143-148.

Ko, H., Campbell, P., Jobin-Décor, M., Eccleston, K., Graham, M., \& Smith, M. (2006). The introduction of transgenes to control blackheart in pineapple (Ananas comosus L.) cv. Smooth Cayenne by microprojectile 
bombardment. Euphytica, 150(3), 387395.

Kodym, A., \& Zapata-Arias, F. J. (2001). Lowcost alternatives for the micropropagation of banana. Plant Cell, Tissue and Organ Culture, 66(1), 6771.

Kofi, O., \& Adachi, T. (1993). Effect of cytokinins on the proliferation of multiple shoots of pineapple in vitro. SABRAO Journal, 25(1), 59-69.

Leifert, C., Pryce, S., Lumsden, P., \& Waites, W. (1992). Effect of medium acidity on growth and rooting of different plant species growing in vitro. Plant Cell, Tissue and Organ Culture, 30(3), 171179.

Liu, L. J., Rosa-Márquez, E., \& Lizardi, E. (1989). Smooth leaf (spineless) Red Spanish pineapple (Ananas comosus) propagated in vitro. The Journal of Agriculture of the University of Puerto Rico, 73(4), 301-311.

Mengesha, A., Ayenew, B., \& Tadesse, T. (2021). Energy sources affect in vitro propagation and subsequent acclimatization of Ananas comosus, var. smooth cayenne plants. Journal of Microbiology, Biotechnology and Food Sciences, 2021, 2372-2376.

Murashige, T., \& Skoog, F. (1962). A revised medium for rapid growth and bio assays with tobacco tissue cultures. Physiologia plantarum, 15(3), 473-497.

Nelson, B. J., Asare, P. A., \& Junior, R. A. (2015). In vitro growth and multiplication of pineapple under different duration of sterilization and different concentrations of benzylaminopurine and sucrose. Biotechnology, 14(1), 35-40.
Page, Y., \& Visser, J. (1989). In vitro propagation of geraldton wax: initiation. proliferation, and rooting. HortScience, 24(2), 381-382.

Rahman, K., Amin, M., \& Azad, M. (2001). In vitro rapid clonal propagation of pineapple, Ananas comosus (L.) Merr. Plant Tiss. Cult, 11, 47-53.

Soneji, J. R., Rao, P., \& Mhatre, M. (2002). Somaclonal variation in micropropagated dormant axillary buds of pineapple (Ananas comosus L., Merr.). The Journal of Horticultural Science and Biotechnology, 77(1), 2832.

Sunitibala Devi, Y., Mujib, A., \& Kundu, S. (1997). Efficient regenerative potential from long term culture of pineapple. Phytomorphology, 47(3), 255-259.

Williams, R. R., Taji, A. M., \& Bolton, J. A. (1985). Specificity and interaction among auxins, light, and $\mathrm{pH}$ in rooting of Australian woody species in vitro. HortScience, 20(6), 1052-1053.

Zaied, N. (2007). Effect of Carbon Sources and Microelement Concentrations on in vitro Proliferation and Rooting of Pineapple (Ananas comosus). Catrina: The International Journal of Environmental Sciences, 2(1), 39-43. 
تأثير درجة الحموضة وتركيز السكروز وحالة الوسط على التجذير المخبري للأناناس صنف كوين عبد الحميد مختار حمد

قسم البستنة، كلية الزراعة، جامعة عمر المختار - البيضاء لبييا

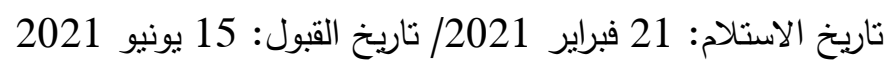
https://doi.org/10.54172/mjsc.v36i2.54:Doi

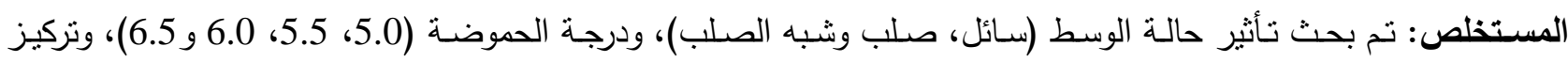

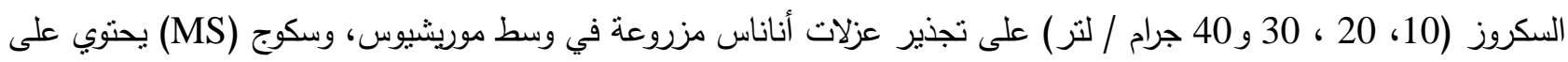

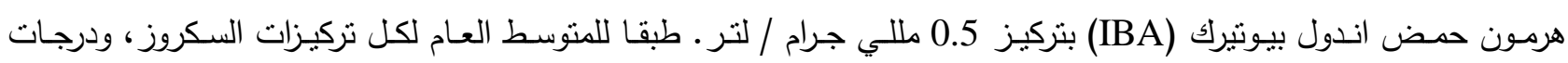

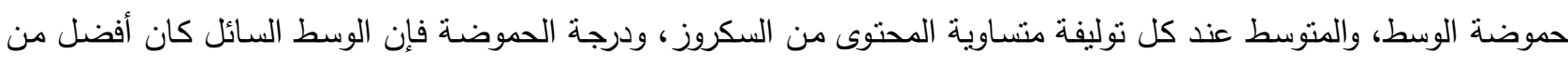

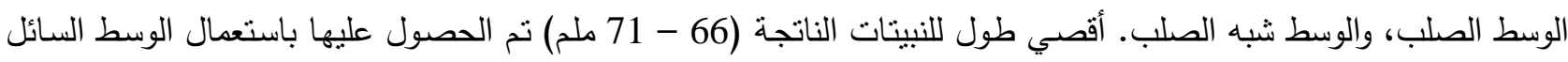

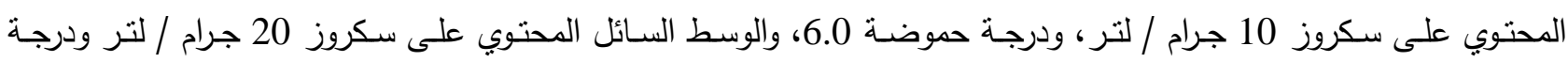

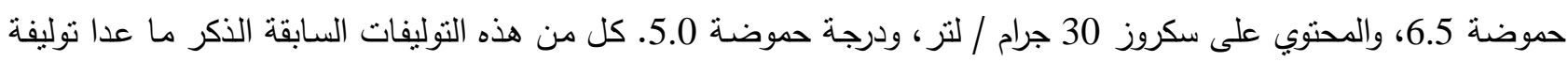

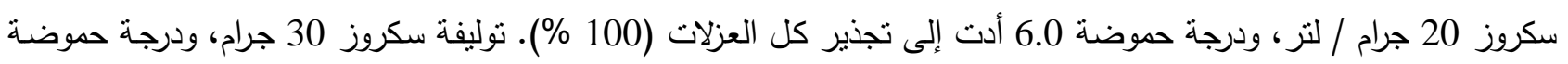

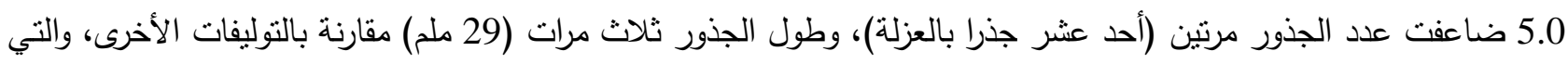

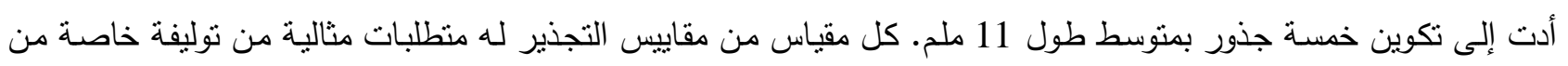

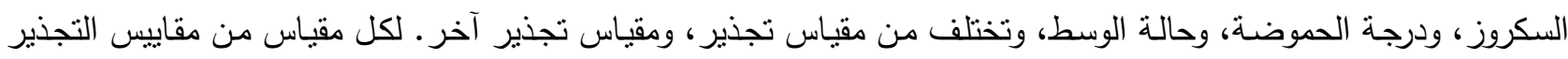

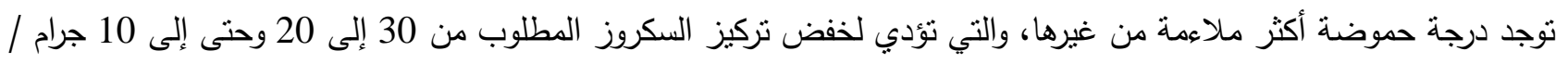

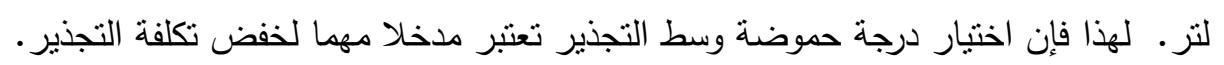
الكلمات المفتاحية: حالة الوسط، درجة الحموضة، السكروز، التجذير، الأناناس. 